\title{
Toward a More Comprehensive Marketing Strategy
}

\author{
Wayne Norvell \\ Kansas State University \\ Manhattan, Kansas \\ Shalini V. Gogumalla \\ University of Alabama \\ Tuscalossa, Alabama
}

C. Glenn Walters

Nicholls State University

Thibodaux, Louisiana

David $M$. Andrus

Kansas State University

Manhattan, Kansas

\section{Sujata Ramnarayan \\ Kansas State University \\ Manhattan, Kansas}

Marketing decisions have expanded over the years with the advent of mass production, mass distribution, and more intense competition in markets. First, mass production and mass distribution led to business concentrating on distribution and selling problems. As the number of buyers and sellers of products increased over the years the element of heterogeneity became significant $([2],[3],[4])$ on both the supply and demand side of exchange. Firms had different capabilities and households had a variety of needs. The process of exchange became more a process of matching heterogeneous product benefits of the firms with heterogeneous consumer needs. Firms realized they must identify consumers with needs they could fulfill. Also, consumers realized they had a choice in purchasing.

The change from a relatively simple marketplace to a multiplicity market with increased competition and wide consumer choice necessitated the implementation of more sophisticated marketing strategy ([1], [15]). It became necessary to identify consumer targets, develop products to fulfill their needs, and price competitively while earning a reasonable return on investments.

The last thirty years has witnessed a higher level of technological sophistication and the implementation of strategic planning ([1], [12], [13]). However, in our zeal to compete more favorably in the marketplace we may have ignored important social, cultural, political, economic and natural environmental goals in our marketing decisions. We experienced the consumerist movement, political and social unrest, environmental problems, and an economy that is still facing difficulty in competing in a world market. We have seen regulation set by both trade associations and various levels of government. These restrictions have been set, lifted, and in some cases reset again with somewhat minimal success.

What is needed is a comprehensive marketing strategy which incorporates the total environment into marketing decision-making. This is the purpose of this paper. First, the pre-consumer orientation period will be discussed in strategic terms. Second,

Journal of Business Strategies, Volume 6, Number 2 (Fall 1989) 
strategic decision-making will be presented in the era of consumer orientation. Finally, a strategic framework will be presented to include the total environment in marketing decision-making.

\section{Strategic Marketing in the Pre-Consumer Orientation Era}

Prior to World War II strategic marketing primarily focused on distribution and sales in the United States. The period from 1900 to 1920 was dominated by transportation decisions. Emphasis was placed by marketers on moving products from manufacturing facilities primarily in the East to potential buyers in the West. Individual firms were focusing on the strategic variable of distribution as a means of unloading excessive supply of product.

This strategy of primarily emphasizing the distribution variable simply transferred stockpiles of products from Eastern manufacturing sites to stockpiles of products in warehouses in the Midwest. Obviously, a strategy was needed to dispose of the stockpiles. The emphasis in marketing now switched to sales. This period of aggressive sales was prominent in the 1920 s and the 1930 s in the U.S.

Business executives started realizing in the latter part of the sales era that a good product, a sound distribution system, and silver tongued salespeople were not enough to compete in an ever increasing competitive environment. This realization coupled with technology derived from World War II led to more rigor in marketing strategy. Alderson ([3], p. 356) stated that sales are a function of organized marketing effort and marketing opportunity, but he never expresses this concept in the form of an equation. Alderson perceived opportunity as basically demand and effort as supply.

Thus Alderson's equation can be stated in the following matter:

$$
S=f(E, O)
$$

In this equation $S$ is sales, $E$ is effort, and $O$ is opportunity. He conceptualized that a business obtains sales as a result of the demand (number of potential customers who have "wants") and the supply (marketing effort by the firm). The marketing effort included product, place, promotion, and price ([7], pp. 2-7).

The emphasis became one of organized firm effort concerning all four marketing mix variables. One must remember that Alderson was looking at marketing from the perspective of the firm. Sales was probably used as the objective of business since it is the first item on the income statement from which all cost and profit must be figured. We will continue to use sales as the objective of business throughout this paper. However, $S$ can stand for any business objective such as customer satisfaction.

\section{Marketing Strategy Under The Consumer Orientation}

The wide acceptance of the marketing concept by businesses in the late 1950s and early 1960 s led to marketing strategy emphasizing the consumer orientation. Emphasis was switched form the supply side of marketing to the demand side with the 
consumer as the focal point. E. Jerome McCarthy ([9], p. 37) was one of the earliest authors to focus on consumer orientation in strategic terms. He identified marketing strategy as a two step process: (1) identification of a target market, and (2) development of a marketing mix. The target market consisted of identified consumers, grouped into segments by similar wants. The marketing mix ([7], pp. 2-7) consisted of coordinated product, place (channel) promotion, and price policies. The marketing $\operatorname{mix}$ was directed at satisfying the wants of segments making up the target. If marketing did its job properly then sufficient sales were generated to cover cost and assure a profit for the organization.

Martin Bell ([6], p. 17) related Alderson's theory to McCarthy's application of marketing strategy and proposed an improved version of the original marketing equation. Bell ([6], p. 17) incorporated the environmental factor and expressed the equation in the following manner:

$$
S=f(O, E, R)
$$

The $S$ is sales. The $O$ is the firm's potential consumers who represent an opportunity. The $E$ is the firm's marketing mix consisting of product, place, promotion, and price policies which represent effort. The $R$ is resistance imposed by environmental constraints on marketing. Thus, the firm achieves its objective by employing a marketing mix designed to satisfy consumers within the constraints of the environment. In this statement of Marketing strategy, the consumer is the objective of marketing effort. The marketing mix is a set of policies, established by the organization and controllable by the management of that organization. The environment is a group of external constraints which are uncontrollable by the organization's management.

Management can react to these constraints, but can do nothing to control them. Since most firms have more than one market segment, it is necessary to expand the marketing strategy formula. It becomes:

$$
\begin{aligned}
S= & f\left[\left(O_{1}, O_{2}, O_{3}, \ldots, O_{n}\right),\left(E_{1}, E_{2}, E_{3}, \ldots, E_{n}\right),\right. \\
& \left.\left(R_{1}, R_{2}, R_{3}, \ldots, R_{n}\right)\right]
\end{aligned}
$$

This expanded version of the formula indicates that sales are a function of several specific marketing efforts directed at, and tailored for, several individualistic consumer market segments within the constraints set by the environment in each case.

Since the original inclusion of the environment into marketing strategy, efforts have been made to make it operational. McCarthy and Perreault [10], Bagozzi [5] and other scholars today, have statements such as "and accomplish the objectives of society" as a part of the definition of marketing. The problem is that when marketing is perceived to focus only on consumers can be included in the decision process. It is contradictory to state that consumer satisfaction in the objective of marketing then admit that other groups beyond the firm's control must also be satisfied. Thus, Bell's marketing equation cannot accommodate environmental objectives. 
Despite its shortcomings, Bell's equation of marketing strategy was a significant contribution. It recognizes the concept of marketing strategy, it identifies the firm and its environment as the important variables affecting marketing, and it pulls the consumer out of the environment. Thus for the first time, marketing strategy was perceived as outward looking to the satisfaction of persons in the environment (at least one group in that environment) rather than completely obsessed with internal efficiency and profit.

it was only a matter of time until it was recognized that other groups making up the firm's environment effect and are affected by marketing in essentially the same manner as consumers. Kotler ([8], pp. 1, 22,24) states "I now believe that marketers can influence the environment in which the firm operates and do not simply have to accept and adapt to it." He suggested that there are six P's with political power and public opinion formulation added to the traditional four P's. Zeithaml and Zeithaml, ([16], pp. 41-53) believe that "marketing is a significant force which the organization can call upon to create change and extend its influence over the environment."

\section{Next Logical Step Towards a Comprehensive Marketing Strategy}

Walters, Norvell and Bruno ([14], pp. 18,23) developed a conceptual framework for marketing which integrates the environment into the decision process. They advance the hypothesis, and that marketing is situational rather than consumer oriented, and this requires a re-definition of the fieid. A situational orientation means that:

marketers develop policies in response to the common wants and interests of identified persons from within all environmental groups in proportion to the importance of each group to the decision.

Based on a situational orientation, marketing can be defined as:

policies to manage and exchange between the firm and its environment to provide products: (1) profitable to the firm, (2) wanted by buyers, (3) legal to governments, (4) competitive with other managements, (5) acceptable to special interest groups, and (6) efficient outlets for suppliers.

This definition requires a marketing strategy sufficiently comprehensive to satisfy together multiple group wants. This approach recognizes that marketing focuses on people rather that either "things" or "ideologies," and people can be influenced. Groups of people can be identified with every aspect of the environment, i.e., competition (other business managers), markets (buyers), legal (government officials), physical (suppliers), and social and cultural (special interest groups). Thus to market managers, governments are not ideologies but agency heads and bureaucrats. Buyers are not demand, rather they are individuals with wants. Social and cultural norms are embodies in special interest groups who promote them. Even the physical environment is represented by persons that marketing managers can influence. They are the suppliers of resources and services, who provide insurance against natural 
disasters, build the stores that allow customers to shop in bad weather, and innovate alternatives to scarce physical resources. The concept of marketing based on a situational orientation causes a necessary adjustment in the statement of marketing strategy. The strategy steps become:

1. Define marketing target (buyers, governments, special interest groups, competitors, suppliers)

2. Develop marketing mix (product, place, promotion, price policies )

The marketing target consists of identified persons form each environmental group that have wants or interests in common that can be appealed to by the firm with a single marketing mix. The strategic marketing equation must be changed to accommodate the situational orientation. The change makes the equation more realistic and comprehensive. The change equation can be stated:

$$
\begin{aligned}
S & =f(M S) \\
\text { where: } M S & =(M M, M T) \\
\text { and: } \partial S / M M & =f(M T) \\
\partial S / M T & =f(M M)
\end{aligned}
$$

In the equation $S$ is sales, or other marketing objectives, $M S$ is marketing strategy, $M M$ is the marketing mix and $M T$ the marketing target.

The first equation specifies that sales is a function of marketing strategy. Marketing strategy is a combination of the marketing mix and the marketing target.

The final two equations involve the interaction between the firm and external groups. Equation two indicates that change in shales that result form a change in the marketing mix is a function of the marketing target. In other words, managers modify their marketing mix due to pressures placed on the organization by the several groups in the environment. For example, pressure form government may cause the firm to change the materials or performance standards of their product. Supplier pressure (sales effort) may induce in their assortment. Pressure from buyers may cause management to lower product price. the fact is that marketing management needs a coherent strategy designed to respond to the needs of all relevant persons in the five environmental groups at the same time.

Even as management responds to external groups, they are utilizing strategy to influence those groups. The third equation specifies that change in sales that results from a change in the marketing target is a function of the marketing mix. Management directs personal selling and promotion at all groups in the environment in order to obtain a desired response from them. For example, Marketing executives meet directly with government officials and also employ lobbyists to influence their decisions. Management designs ads that, simultaneously, appeal to buyers, specify government 
standards, employ positive stereotyping for special interest groups and meet competition. Thus it is obvious that sales result form a total interaction between the firm and its environment.

The marketing equation has to account for the fact that most firms appeal to more than one marketing target at a time. The equation must be modified as follows:

$$
S=f\left(M S_{1}, M S_{2}, \ldots, M S_{n}\right)
$$

That is, a marketing strategy must be developed for each marketing target to which the firm is attempting to appeal. Management will not attempt to enter a target, or continue operations in a target market where the actions of even one group is prohibitive. For example, a firm would not enter (1) a target market that lacked sufficient buyers, (2) a target where competition was so intense as to preclude adequate sales, or (3) target where government regulations made it impossible to make a profit, or (4) target where there was an absence of adequate suppliers of land, labor, and capital.

There are four fundamental differences between the situational orientation to marketing and the consumer orientation as demonstrated by the marketing strategy equation presented above. First, the situational orientation broadens the objective of marketing from consumer satisfaction to include satisfaction for all groups in the environment. Second, a situational orientation specifically recognized the need for the firm to make a profit, as well as satisfying the needs of the external environment.

Third, the buyer, in a situational orientation, is a more inclusive term than consumer. The term consumer is generally taken to mean final household consumer, and under a consumer orientation only households are specified as the goal of marketing effort. The term buyer includes institutions as well as final consumers, and it is the buyer that is the goal of situational oriented marketing.

Fourth, under the situational orientation, the environment is not perceived as an uncontrollable constraint. Management can affect the environment in which they operate. Managers take specific action directed at all groups in the environment to reward behavior consistent with the firm's objectives and to change behavior that is inconsistent.

\section{Marketing Strategy in the Future}

This explanation of the progressive development of marketing strategy has been necessarily sweeping. There is much work to be done. The impact of a situational orientation is just now beginning to be felt. Many refinements will no doubt be necessary over time. The implications of the changes that this broadened perspective has on marketing practice will have to be fully explored. Most importantly, the equation itself must be tested for theoretical consistency and relevance to the real world. 


\section{Summary}

Due to the complex nature of marketing, the marketing manager is confronted with a great deal of uncertainties in marketing decision-making. However, the odds for success improve if the manager deals with the situation in realistic-comprehensive terms.

Initially, the marketing strategy centered on directing marketing effort in relation to an understanding of demand. The objective was to make the most out of a market opportunity.

Later, marketing scholars recognized environmental constraints on marketing programs. Thus, a firm achieved its objective by employing a marketing mix designed to satisfy consumers within the constraints of the environment. Consumers become the objective of marketing effort. The environment is a group of external constraints which are uncontrollable by the management of the organization. Management only has control over the marketing mix within the context of the total environment. However, this approach does recognize the concept of marketing strategy. It identifies the firm and its environment as the important variables affecting marketing, and it pulled the consumer out of the environment. For the first time marketing strategy was perceived as outward looking to the satisfaction of consumers in the environment rather that obsessed with internal efficiency and profit.

Viewing the external environment groups, except consumers, as uncontrollable tends to cause managers to take these groups for granted or to simply react to existing conditions. In either case, management is missing a opportunity by ignoring the goals of these external groups.

A more comprehensive marketing strategy and decision model is presented in this article which enables the marketing manager to fully integrate the external environment into marketing strategy. Marketers must realize that all external environment groups affect and are affected by marketing decisions. Managers must evaluate which environmental variables affect a given marketing decision and to what degree. The response should be positive and designed to manage the attitudes and behavior of external groups.

This more comprehensive marketing strategy enables marketing managers to develop marketing plans that are more comprehensive, realistic, and effective in the competitive world. The result should be a higher level of goal attainment by all groups in the environment plus greater efficiency and profits by firms.

\section{References}

1. Abell, Derek F. and John S. Hammond. Strategic Market Planning. Englewood Cliffs, NJ: Prentice Hall (1979).

2. Alderson, Wroe and Reavis Cox. "Toward a Theory of Marketing." Journal of Marketing, Vol. 13 (October, 1948), pp. 137-152.

3. Alderson, Wroe and Reavis Cox. Marketing Behavior and Executive Action. Homewood, IL: Richard D. Irwin (1957). 
4. Alderson, Wroe and Reavis Cox. "The Analytical Framework for Marketing." Delbert Duncan (ed.), Proceedings: Conference of Marketing Teachers from Far Western States, Berkeley, CA: University of California (1958).

5. Bagozzi, Richard P. Principles of Marketing Management. Chicago, IL: Science Research Associates, Inc. (1986).

6. Bell, L. Martin. Marketing: Concepts \& Strategy. Boston, MA: Houghton Mifflin Company (1966).

7. Borden, Neil H. "The Concept of the Marketing Mix." Journal of Advertising Research, (June, 1964).

8. Kotler, Philip. "Rethink the Marketing Concept." Marketing News, (September 16, 1984), pp. 1, 22, 24.

9. McCarthy, E. Jerome. Basic Marketing: A Managerial Approach. Homewood, IL: Richard D. Irwin, Inc. (1960).

10. McCarthy, E. Jerome and William D. Perreault, Jr. Basic Marketing: A Managerial Approach. Homewood, IL: Richard D. Irwin, Inc. (1984).

11. Oxenfeldt, Alfred R. "The Formulation of a Market Strategy." In Eugene J. Kelley and William Lazer, Managerial Marketing: Perspectives and Viewpoints, Homewood IL: Richard D. Irwin, Inc. (1958).

12. Porter, Michael E. "How Competitive Forces Shape Strategy." Harvard Business Review, (March-April 1979).

13. Porter, Michael E. Competitive Strategy. New York, NY: The Free Press (1980).

14. Walters, C. Glenn, D. Wayne Norvell and Sam J. Bruno. Basic Marketing: A Situation Orientation. Bessemer, AL: Colonial Press (1988).

15. Smith, Wendell R. "Product Differentiation and Market Segmentation As Alternative Marketing Strategies." Journal of Marketing, Vol. 21, No. 1 (July, 1956).

16. Zeithaml, C. and V. Zeithaml. "Environmental Management: Revising the Marketing Perspective." Journal of Marketing, (Spring 1984), pp. 41.53. 